\title{
Examining the Significance of Service Learning in Driving the Purpose of a Rural-Based University in South Africa
}

\author{
Maphosa Cosmas \\ University of Fort Hare, South Africa \\ Email: cmaphosa@ufh.ac.za \\ Mudzielwana Ndileleni Paulinah \\ University of Venda, South Africa \\ Netshifhefhe Lufuno \\ University of Venda, South Africa
}

\section{Doi:10.5901/mjss.2014.v5n16p302}

\section{Abstract}

In line with established mission and vision, a university articulates its focus and purpose of existence. The conduct of business in a university should be for the furtherance of the institution's mission and vision. Teaching and learning should play a pivotal role in driving the purpose of a university. In this paper the researchers examine how service learning could be significant in driving the purpose of a rural-based university whose focus is to promote rural development. The importance of an institution's vision and mission statements is explored and the vision and mission of the said university examined closely. The concept rural development and the contribution of a university in its promotion are discussed. Service learning as a teaching and learning approach is examined and its significance in driving the purpose of a rural-based university explained.

Keywords: Relevance. Differentiation. Purpose. Teaching and learning. Research.

\section{Introduction}

A common criticism levelled against universities is that they stand as ivory towers in society. This suggests that universities are often disconnected from the everyday realities of the communities in which they are located. Servicelearning is viewed as a type of experiential teaching and learning strategy which combines classroom instruction and meaningful community service and guided activities for reflection (Rosenkranz, 2012). To this end, teaching and learning are geared towards serving communities by way of addressing the felt community needs and students are engaged in real-world application of knowledge.

On the argument that universities should work closely with communities, Pearce, Pearson and Cameron (2007:5) state that:

Universities should become increasingly valued by their local communities and less intimidating, elitist and impenetrable. By looking 'beyond the ivory tower', universities can help to build a learning and knowledge based society for the many not just the few.

Universities, in this regard, should not stand aloof from communities but should be involved in working closely with communities to solve community challenges. Communities should look up to universities for solutions and any university whose pedagogical approaches are rooted on service learning is bound to bridge the gap between universities and communities. Policy Analysis and Advocacy Programme (PAAP) (2008:1) calls for the mind-set change for academics in universities in order to embrace changes of the traditional university in ensuring close link with communities by stating that: 
make a paradigm shift so that universities become an integral part of the communities that support them.

The need for universities to work closely with communities in which they operate is very important in ensuring relevance of higher education. Teaching and learning cease to be theoretical but practical as students and lecturers will be involved in solving real life problems experienced in communities.

Regarding Agriculture Faculties in universities, PAAP (2008:3) pass the advice that:

The university must skilfully identify competence gaps of professionals, farmers, policymakers and other agricultural stakeholders, through collaborative learning for change.

In this regard, universities will be responsible for the skills empowerment of community members and, invariably, increase in productivity. It will be unfortunate and ironic for community members to experience challenges which they can work collaboratively to overcome with the local university.

\title{
2. Importance of Mission and Vision Statements to Institutions
}

Most organisations, including institutions of higher learning, operate with clear mission and vision statements. Darbi (2012:1) observes that:

\begin{abstract}
Mission and vision statements have been overwhelmingly accepted as an indispensable part of the strategic management process for organizations of all types; be it public sector, not-for-profit, private, for profit, a multinational or a small and medium scale enterprise. It is widely believed that mission and vision statements impact on strategy and most aspects of organizational performance.
\end{abstract}

Mission and vision statements are aligned to an organization's strategic plan and assist in shaping the attainment of the strategic plan.

According to Ozdem (2011), vision statement refers to the long term objectives of the institution. Vision shapes and guides future business practices and also defines what the organizations wants to become in the future and which positions it desires to acquire, and it is also the expression of a dream concerning a future desired state. In this view, Morphew and Hartly (2006:45) state that:

Mission statements are valuable because they - and the elements within them - show that the organization in question understands the "rules of the game." And, one of the rules of the higher education game is that you have to have a mission statement if you want to be considered a legitimate college or university by, among others, accrediting agencies and board members.

The vision and mission statement defines the institution's reason for its existence and where it wants to go in future. They embody the institutions philosophies, goals and ambitions. The vision and mission statement serves as a route navigation system which tells the institution where it needs to go and to stay in the relevant route. One can define a vision as a look towards the unknown to define the future, which combines current facts, hopes, dreams and opportunities that the institution can set.

Darbi (2012) further observes that vision and mission statements have become a road map for the institutions, both in the private and public sector including the Higher education institutions. They have now become a cornerstone of any strategic plan. Darbi (2012) further argues that vision and mission statement had consistently shown to be the top-rated management tool deployed by the senior management and are useful for the practical day-to-day operations. Vision and mission statements can be used to build a common and shared sense of purpose and also serve as conduct through which employees focus are shaped. Darbi (2012) believes that vision and mission tend to motivate, shape behaviors, cultivate high level of commitment and ultimately impact positively on the employee performance.

Darbi (2012), also makes an important observation in terms of the marketing of the institution's vision and mission to say that, while the research suggest that the vision and mission statement have a positive impact on the profitability and can increase stakeholders trust in the institution, they also reported that almost forty percent of employees do not know or understand their institutions vision and mission. Darbi (2012:96) advises that:

... institutions should ensure the awareness of existing vision and mission statement and its purpose, and also make awareness of the content or components of vision and mission statement and how it relates to employees.

Vision and mission statements are widely believed to be precursor to any strategy formulation effort. Darbi (2012) 
further argues that mission statements are supposed to capture the overriding purpose of an institution in line with the values and expectations of stakeholders and shows typically answer the question: "what business are we in"? And what is our business for?"

Opiyo-Newa (2009) concurs with Darbi (2012) on the importance of the vision and mission to say, vision and mission statements are of fundamental importance for every organization. It is said that without a vision people perish. Such a view is supported by Darbi (2012) in that that there seems to be an overwhelming consensus that vision and mission statements are communications tools for both internal and external stakeholders. They communicate institutions uniqueness in terms of its ownership, recourses and environmental circumstances. Vision and mission statements assist in distinguishing an institution from other institutions (Darbi, 2012:97). The primary role of the vision and mission statements is to communicate the strategic decision of the institution to the stakeholders in order to guide strategic planning.

Opiyo-Newa (2009:112) argues that a mission statement summarizes the basic definition and direction of an institution by stating that:

By giving a mission statement the University is giving a promise to the students and society in general that if they join their institution, they will be able to come out with the given outcomes.

The vision and mission of all higher education institutions should self-evident and give confidence to the community that they will provide good quality teaching and learning for their students, conduct valuable research, and ensure that community engagement will be executed as this are the core business of every higher education institution.

According to Ozdem (2011), strategic management and strategic planning aim to create a permanent loyalty to the mission and vision of the organization, and to nurture a culture that defines and support mission and vision statements. Mission and vision statement guide all activities of organization and businesses. Thus, these decision need to be made after careful consideration so that they can contribute to the planning and implementation of other activities of the organization. Ozdem (2011) further argues that the function of the mission statement is to guide the whole process of strategic planning because the mission states what the organization wants to be and who it serves. Mission statement expresses the raison detre of an organization, and aims to bring together various components of the organization around a common Couse, to provide a strategic orientation for the organization, and to make sure resources are used within this framework. He further elaborated that a mission is the reason for being of an organization when an organization prepares strategies of making choices between different alternatives, mission statement guides the strategies. According to Ozdem (2011), a well prepared mission statement needs to identify the specific purpose of the organization and its field of activity in terms of products and markets, and thus differentiate the organization from others.

This is supported by Morphew and Hartly (2006), to say mission statements are ambiguous in Higher education. Accreditations agencies demand them, strategic planning is predicated on their formulation, and virtually every college and university has one available. Others point to the value of the mission statement in expressing a "Vision" for the institution's future. Morphew and Hartly (2006:457) further argues that:

\footnotetext{
... the process of articulating an institution's mission has two potential benefits which are: first, it is instructional, that's, a clear mission helps organizational members distinguish between activities that conform to institutional imperatives and those that do not, second, a shared sense of purpose has the capacity to inspire and motivate those within an institution and to communicate its characteristics, values, and history to key external constituents.
}

Ozdem (2011) proposes that a mission statement should be a reason for being of an organization. When an organization prepares strategies of makes choices between different alternatives, mission statement should guide the strategies. He further remind us that a well prepared mission statement needs to identify the specific purpose of the organization and its field of activities in terms of products and markets, and this differentiate the organizations from others.

In the South African higher education context, the mission statement reflect the institutional diversity of South African higher education then the proponents of mission statement may be right - mission statement may be a way of establishing institutional uniqueness and therefore are a potentially useful tool in institutional decision making (Morphew \& Hartly, 2006).

According to Ozdem (2011), mission statement should be clear, concise, and intense. They should define the purpose of the organization's identity the people and organization serves, they should state the field of activity of the organization and they should mention the needs served by the organization. Ozdem (2011) further argues that a vision statement is another important element of strategic planning. When institutions have a strong vision, it helps them predict 
future events, be prepared for changes and innovations, have courage to face the future, predict changes in customer demand and improve employee efficiently.

Ozdem (2011) suggested that during the formulation of vision and mission statement of the Universities, important variables such as the reason for being of the university, the environment within which it is located, its human resources, aim and objectives, target audience, field of service and the needs the university aims to address should be taken into consideration. It is important that a vision should be revised to check its relevance in the ever changing world. Diamond (2002), cited in Smith (2005), states that:

Each institution must have a mission statement that is consistent with institutional values and that guides its work.

Smith (2005) argued that before an organization can formulate a strategy it must contemplate its mission, values, and vision concepts that are at the core of any effective organization because they inspire stakeholders, guide decisions, and can be used to align the actions of every employee.

If an institution operates without a mission and vision statements, it risks wondering off mission and wasting time and resources trying things which are at best peripheral and at worst irrelevant to the objectives it should be trying to achieve.

\section{A Rural-Based South African University's Mission and Vision in Relation to University's Purpose}

The university saw a tremendous change with the advent of democracy in 1994 where a new leadership at the helm was introduced. From 1995, the University shifted its focus to science and technology, which resulted in the introduction of new programmes with an increase in student enrolment in the natural and applied sciences.

In line with what Ozden (2011) argues, the vision and mission shapes and guides future business of the institution and what the institution wants to become in the future and which position it desires to acquire. During each stage of transformation, the University aligned its vision and mission to the needs of the community at local, regional, national and international context. Darbi (2012), argued that the vision and mission can build a common and shared sense of purpose and also serve as conduct through which employees focus are shaped. This is confirmed by the fact that the university's transformation and revamping of its vision and mission process also created significant changes in the administrative governance and in the size and shape of the curriculum and therefore also attracting better qualified staff and resulted in improved student profile.

The current vision of the University is "to be at the centre of tertiary education for rural and regional development in southern Africa". Situated in the rural part of South Africa the University's vision is to do best in developing the area is situated in. This is confirmed by its "Rural and regional Development" in the vision.

This rural based university as one of the twenty-three universities in South Africa is financed by the Department of Higher Education and Training and therefore the Department on Higher education has powers to give mandate to the Universities. The Department of Higher Education and training gave the University a mandate to transform from a traditional university into a comprehensive university that offers academic professional and vocational programmes. In the process of transforming to be a comprehensive institution, the University also aligned its mission as a reason of its change and existence in line with where it wants to go in the future.

The mission of the University is:

As a comprehensive institution, the University offers a range of programmes that are responsive to the development needs of Southern African region, using appropriate learning methodologies and research.

The mission of the University captures its overriding purpose and gives its stakeholders expectations. It outlines what business the University is in and what is its business for as argued by Darbi (2012). This mission reflects the university's uniqueness and also guides the university to its 'promised land'. The University's mission expresses strategic orientation for the University and also guides the strategies. One of the core values of the university is social responsibility, community engagement and Ubuntu, suggesting the university's desire to link with communities in addressing societal challenges.

From the University's mission, vision, mandate and institutional values, one can conclude that the University shares sense of purpose has the capacity to inspire and motivate those within itself and also to communicate its characteristics, values, and history to key external and internal stakeholders. The University's vision and mission statement reflect its consistency with institutional values and guides its work. The programmes that the university is currently developing speaks to its mandate, vision and mission, conforming to the requirement by the Higher education quality committee (HEQC) of the Council of Higher Education (CHE) criteria for programme accreditation. The HEQC's 
criterion for programme accreditation requires that each institution going through the programme accreditation should ensure that its programmes are speaking to its mission CHE (2004).

According to the CHE (2004:12):

The programme is consonant with the institution's mission, form part of institutional planning and resource allocation, meets national requirement, the needs of students and other stakeholder's, and is intellectually credible. It is designed coherently and articulates well with other relevant programmes, where possible.

As a requirement of the HEQC of the $\mathrm{CHE}$, every institution mission should reflect what is elaborated above, i.e., talking to the institutional, regional, provincial, national and international needs. The University mission is well stated in such a way that it covers the requirements by the HEQC, it satisfies HEQC's regulatory requirement as argued by Smith (2005), that the University's vision and mission statement should reflect the distillation of the strategic activity of the institution.

\title{
4. Relevance, Diversity and Differentiation in Higher Education
}

Higher education should serve to promote needs of the regions in which they are located. This ensures relevance of the education offered. On the importance of higher education in promoting regional needs, Chatterton and Goddard (2000:475) state that:

\begin{abstract}
Being located 'in' regions, universities and colleges are asked by a new set of regional actors and agencies to make an active contribution to the development 'of' these regions. These demands are driven, amongst other things, by processes of globalisation and regionalisation (or localisation) in economic development, whereby the regional (or local) environment is as relevant as the national macro-economic situation in determining the ability of enterprises to compete in the national, supra-national and global economies.
\end{abstract}

The above observation hinges on the important realisation that universities should be agents of change in the local communities. In as much as universities seek to be global in appeal there is need to address needs of communities in different localities.

In arguing for differentiation of institution of higher learning Higher Education South Africa (HESA) (2012: 3) observes that:

\footnotetext{
... there is no virtue in entirely homogenous universities, or the pursuit of absolute homogeneity, where every university seeks to be the same and to undertake exactly the same purposes and functions. Nor is there any value in universities all aspiring to become 'traditional universities' or towards the supposed 'gold standards' of the 'world class' or 'research university.'
}

Of importance is the need for each university to define its purpose and channel resources towards the achievement of such purpose. Universities become unique as they seek to achieve different purposes in line with their missions and visions.

The UNESCO's 'Framework for priority action for change and development of higher education' (1998) cited in Chatterton and Goddard (2000:477) states that higher education institutions should:

Develop innovative schemes of collaboration between institutions of higher education and different sectors of society to ensure that higher education and research programmes effectively contribute to local, regional and national development.

This shows the importance of synergies between universities and local communities in the promotion of regional development.

\section{The Concept Rural Development}

The concept of rural development is used differently and has been defined differently by various authors and has developed through time as a result of changes in the perceived mechanisms and or goals of development. Anríquez and Stamoulis (2007) argue that a reasonable definition of rural development would be to look at it in terms of development that benefits rural populations. Such development is meant to improve the standards of living or welfare of the rural inhabitants.

According to Anríquez and Stamoulis (2007) this definition of rural development, however, has to be further qualified. In the 1960's and early 1970's the consensus was that intense industrialization was the main characteristic of 
the perceived development path. In this context it seemed natural to define rural development as precisely leading into that path: "Rural development is essentially a part of structural transformation characterized by diversification of the economy away from agriculture. This process is facilitated by rapid agricultural growth, at least initially, but leads ultimately to a significant decline in the share of agriculture to total employment and output and in the proportion of rural population to total population." (Johnston, 1970:371).

Later during the 70's, mostly based on equity considerations, the focus and definition of rural development turned to the provision of social services to the rural poor. This shift was partially founded on the recognition that even under rapid growth of income in rural areas, the availability or equitable access to social services and amenities was not guaranteed (Gustavo, Lovendal, Nordanstad \& Stamoulis, 2005).

This shows that rural development is a process that can enable the rural people with skills to improve their lives. Of importance is that they should be able to sustain their projects by themselves. According to the World Bank (1975) and Agarwal (1989) rural development is defined as a plan of action meant to upgrade economic and social living conditions, focusing on a specific group of poor people in a rural area. It should be beneficial to the rural folk.

Rural development also entails the application of approaches and techniques I different community-based programmes, in which rural people work as communities to enhance their livelihoods. This fosters the spirit of togetherness, which is an important element of Ubuntu. Similarly, Chauhan (2012:3) states that:

Rural Development $(\mathrm{RD})$ is a process, which aims at improving the wellbeing and self-realization of people living outside the urbanized areas through collective process. Therefore a close look at rural development needs a collective of ideas and not a one man's show.

The United Nations (1997 (cited in Chauhan 2012:3) defines rural development as a process of change, by which the efforts of the people themselves are united, those of government authorities to improve their economic, social and cultural conditions of communities in to the life of the nation and to enable them to contribute fully to national programme. Rural Development is a process of bringing change among rural community from the traditional way of living to progressive way of living. It is also expressed as a movement for progress.

It is, therefore, important that rural development programmes must strive to prepare people on the ground so that they can own them for survival by providing support prior to the starting of the programmes. Umbau (2008) makes an observation and discusses the concept rural development in many ways: Umbau (2008), Chambers (1983), Singh (1999), CRDP (2009), World Bank, 1975) state that rural development should seek to enhance rural resource productivity, enhanced food production, rural infrastructure development, improved living standards, among many other issues.

Atchoarena and Gasperini (2003:26) support the above observation and state that:

... rural development: encompasses agriculture, education, infrastructure, health, capacity-building for other than onfarm employment, rural institutions and the needs of vulnerable groups.

Atchoarena and Gasperini (2003) further indicate that the aims is improving rural people's livelihoods in an equitable and sustainable manner, both socially and environmentally, through better access to assets (natural, physical, human, technological, and social capital), and services, and control over productive capital (in its financial or economic and political forms), that enable them to improve their livelihoods on a sustainable and equitable basis.

According to Olayiwola and Adeleye (2005) the concept of rural development may be used in different ways in vastly divergent contexts. Centred around income criterion in which the concept is made to address the problem of rural poverty; or in sociological concept in which the rural poor represents a reservoir of untapped talent-a target group that should be given the opportunity to enjoy the benefits of development through improved education, health and nutrition..

Olayiwola and Adeleye (2005) further highlights that rural development may also be seen as an ideology and a practice; and may mean planned change by public agencies based outside the rural areas such as the National Government and International organisation and bringing the country side into something more superior in terms of activities.

Lele (1975), Abakare (1977) and Mobogunje (1981) cited in Olayiwola and Adeleye (2005) view rural development as the improvement in the living standard of the rural dwellers by engaging them in productive activities such as the establishment of rural industries that will increase their income. This implies that the focus is on improving the lives of the people in the rural areas. In this paper researchers define the concept rural development as may imply a broad based reorganisation and mobilisation of the rural areas to improve the quality of life of rural people; which includes social, economic, political and spiritual development of the poorer sections of the society and which lead to sustainable improvement. 


\section{The Role of a University in Rural Development}

There is a need for a shift in the thinking of universities for new or alternative models of rural development with diversified approaches, which make proper use of local resources and knowledge for sufficiency while making profit as well. In April 2009 , with the advent of the Zuma Presidency in South Africa, rural development became one of the key priority programmes for the next five years (2009-2014). For learning to be very important in a knowledge economy; universities are therefore called to become an important role for promoting innovation (Mowery \& Sampat, 2005). This implies that universities are seen as potential facilitators of the innovation activity aiming to find responses to rural needs and this requires universities' commitment for innovation capacity development and social compromise (UNESCO, 2006, Mowery \& Sampat, 2005). Higher education is the dynamic power needed by any countries for social and economic development, since universities are regarded as a framework of nurturing high quality. This implies that rural people must be at the centre of university concerns and therefore universities must provide assistance to the rural communities.

\section{Producing Ideal Graduates}

Universities can serve the rural population in various ways. Raman (1999) asserts that rural development is a comprehensive and multi-dimensional concept with an objective of improving the quality of life of the rural people. It can be achieved by the development of agriculture and allied activities, socio-economic infrastructure and human resources through skills development and improvement. University can provide higher education to the public, by producing graduates who will serve in their communities. It is important that rural universities must include subjects that include analysis and description of the process of change as well as methods and activities aiming at local development.

This implies that graduates will enable a specific group of people to know and to come up with strategies on how to assist themselves. In order to contribute positively students should have not only the theoretical foundation but also the ability to solve practical problems in the course of agricultural production. This implies that students' practical ability can be improved through research and this should be the goal of academics. Universities located in rural communities should directly contribute to developing human resources in these communities through offering various degree programmes and short courses.

Of importance academics should prioritise on subject areas of concern in the community have more immediate and visible impact on the development of the community, such as those related to agriculture, health and various aspects of community life. This means that the programmes offered will be sustainable

To strengthen the link of teaching and practice means to strengthen the teaching in the experimental classes and even more in the very spots of production through the consumption of goods and services by university personnel and students (Cabanatan, 1999). This implies that graduates should be able to apply theory into practice so that the programmes should be meaningful to the people.

\section{Research}

Doing extensive research the student will gain valuable experience in various fields in response to both academic and societal demands.

Hekkert et al. (2007) cited in Ramirez (2010:26 ) state:

... that today the university is a place of research, instruction and consultation. This implies that universities can conduct research and development in areas directly concerned and of benefit to rural development.

Cabanatan (1999) confirms that institutions of higher learning with a strong research orientation can use information gathered from their research activities in rural development through rural problem advocacy. This means that through research students learn to practice methods of social research, for example collecting and analysing data related to the needs of the communities and so develop a strategy to address the problems. In a way through the exposure to research, students learn to improve the quality of life of the rural people.

This implies that research is accepted as being a necessary university function. The process of research fosters the spirit of inquiry and that it helps to keep student and up-to-date or on the new knowledge in the field. This in turn requires lecturers who are competent to ensure the intellectual standards of teaching and learning. Subrahmanyan and Ravichandran (2013:25) state that: 


\begin{abstract}
Universities need to do necessary research in order, to understand the root cause of any problem and need to invent custom-made solutions in order to address the problem satisfactorily, effectively and efficiently. Universities should not limit themselves with the current problems but, should foresee the upcoming and future problems and should be ready with solutions to tackle them successfully.
\end{abstract}

This means that it is important that the universities should be innovative and be proactive and become testing laboratories where new methods and ideas can be tested before they are being employed by the communities.

Through research universities can play a role in influencing policy makers as they will have hands -on experience about the needs of the communities. Through the knowledge gained in research activities where there are gaps universities may propose alternative management directions for rural development (Cabanatan 1999). Subrahmanyan and Ravichandran (2013:25) state that:

Universities should also do a continuous evaluation of government policies in order to check whether the fruits of the policies are reaching the specified target groups or not?; and of on-going or implementing projects for both their success and failures. For example, if the model is found failure, after careful evaluation one can know the actual mistakes due to which the model went failure.

Universities may introduce technological innovations and solving problems. Information technology (IT) serve as a solution by broadening the scope of their programmes and perspectives vis-a-vis rural development, and to providing flexible extension services and training programmes. According to Hekkert et al. (2007), this function emphasises that technological change is not autonomous. Changing preferences in society, if strong and visible, can influence rural development priority setting and thus the direction of technological change.

Universities can contribute to this function by analysing and assisting in the evaluation of technologies, processes and policies tasks include educating more and better qualified personnel, producing more scientific research achievements and transferring the achievements into productive powers as soon as possible (Hall et al., 2006). This implies that there should be sufficient funds for the academics to carry out experiments.

\title{
9. Rural Extension Programmes
}

In order to address the needs of the communities, rural extension programmes should become an integral part of the curriculum. This can be achieved through expanding academic services to include such things as short-term training courses, seminars, workshops, run training courses and give lectures on modern agricultural knowledge and techniques to farmers co-operate with farmers' enterprises to transfer the university's scientific research achievements to farmers and enterprises and to develop a new way to contribute to education with research and production to the rural area populations and can be active participants in agricultural management, vocational training, and educational professional development.

Ping (1998 cited in Atchoarena and Gasperini (2003) states:

Universities are no longer tied to their buildings but have moved out to search for and serve the greater population rather than wait for students from rural and provincial areas to amass enough money to be able to move into the cities to further their education.

This implies that universities staff should not wait for students to come to the campus for studying; they should have enough funding to can go out to where the rural communities are and offer programmes according to their specific needs and this needs funding. To this end, it is clear that there is ample justification to prioritise the priority alleviation in order to raise their standard of living of the rural poor. There is a need for reform in universities to be able to respond to the real needs and demands of the society, particularly the local communities and to be able to contribute to rural development in a practical manner.

It should be the mandate of the rural universities to be able to grasp and address the real issues and problems of the poor rural areas in their own country. Of importance is to see to it that there is adequate materials, resources, and even decision-making power, to carry out rural development programmes on their own. Universities should try to integrate different activities, into their existing programmes. The success of integrated programmes by universities for rural development is not reliant on the financial resources, but the commitment of the people to make the programme work, on both sides.

Universities are supposed to play an important role in promoting innovation (Mowery \& Sampat 2005). Universities also have a direct role to play in poverty alleviation. The vast majority of poor people in developing countries live in rural areas and education is a key factor in helping to reduce the level of poverty. In this context, the relationship between 
higher education and rural development is becoming an important policy concern, particularly in countries where the revitalization of rural areas represents a critical challenge (Atchoarena \& Holmes, 2004: 16)

\title{
10. How Service Learning Can Drive the Purpose of a Rural-Based University
}

Bennett, Henson and Drane (2003) define service learning as an educational process where students are guided and educated through a volunteer experience in communities that allow them to observe, practice, and deliver skills and services taught in the classroom. In this view, learning in a rural-based university should be immersed in community activities so that students learn by engaging in active and real-life learning experiences (Buchanan, Baldwin \& Rudsill, 2002).

Service-learning is a teaching and learning approach that integrates community service with academic study to enrich learning, teach civic responsibility, and strengthen communities. Furco (2002:25) states that service learning:

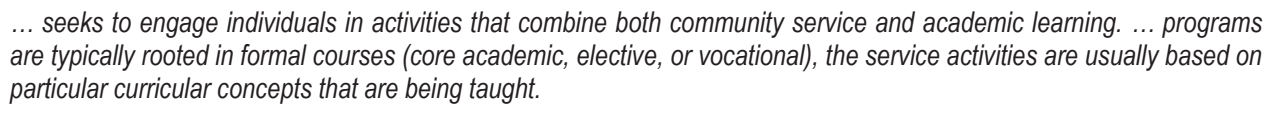

Learning ceases to be theoretical and only confined to classrooms. Students actively participate in community work. This allows students to have a broader appreciation of the discipline, and an enhanced sense of civic responsibility (Bringle \& Hatcher, 1996).

On the significance of collaboration between schools and institutions of higher learning and communities, Miller $(1995: 164)$ asserts that:

\begin{abstract}
Schools and communities in some rural areas have begun collaborating to provide experiences for students that serve both educational and community development goals...The long-term benefits of these school community partnerships may include leadership development, renewed civic responsibility, and a revitalized sense of community.
\end{abstract}

In this view, servicing learning becomes mutually beneficial to institutions and to communities. This is consistent with Jacoby and Associates' (2003) view that service learning enables schools to meet their learning goals while making unique contributions in addressing community issues.

Isaacson and Sapertein (2005) observe that one of the benefits of service learning is that it provides students with opportunities to practice the skills and concepts learned from their courses. Through learning by doing students derive enjoyment and motivation to achieve more compared to the traditional lecture type of teaching in the classroom. Swick (2001) also observes that service learning allows students to learn by being involved in solving community problems, which teaches them to be problem solvers.

The Green Paper on Higher Education Transformation (DoE, 1996) notes that the South African Higher Education system has challenges in ensuring a sense of citizenship among graduates as well as addressing societal needs. Through service learning, a rural-based university may drive the purpose of addressing community needs. This ensures the advancement of the university's social responsibility by promoting and developing social responsibility and awareness amongst students of the role of higher education in social and economic development through community service programmes.

\section{Conclusions}

In this presentation the researchers have shown the importance of the university to design programmes that are line with the mission and vision and to make sure that the agenda in a rural-based university include service learning programmes. It became clear that the university the university should not be a stand-alone institution but must be connected or linked with the communities they serve so that the programmes can meet the specific needs of the communities; hence to become increasingly valued by the local communities. Educating academics to change their mind set to be willing and committed to embrace the local communities should remain the focal point.

\section{Recommendation}

a) Service learning should be taken seriously by university. Rural-based universities should design skills development programmes to the local communities. 
b) Academics should therefore prioritise on focussing on subject areas that will be of concern to the communities in order to achieve a visible impact on the development.

c) University should encourage graduates to be actively involved in community research through the various degree programmes.

d) Universities, in collaboration with relevant agencies, should examine their roles in the rural community development in terms of whether being adviser, partner or implementer, and determining the extent to which it will play each role.

e) There should be a strong partnership between university and the government in order to inform policy makers about the gaps and the necessary improvement identified through research.

\section{References}

Abakare, C.O. (1977). The concept of rural development. summary of P.A.O. Cairo: Inter-regional Seminar on Integrated Development.

Atchoarena, D., Gasperini, L. (2003). Education for rural development: towards new policy responses. A joint study conducted by FAO and UNESCO. Food and agriculture organisation of the United Nations. Rome: FAO.

Atchoarena, D., Holmes, K. (2004). The role of agricultural colleges and universities in rural development and life-long learning in Asia (15-24). Asian Journal of Agriculture and Development. Accessed 21 December 2013.

Bennett, G., Henson, R., Drane, D. (2003). Student experience with service learning in sport management. The Journal of Experiential Education, 26(2): 61-70.

Buchanan, A., Baldwin, S., Rudsill, M. (2002(. Service learning as scholarship in teacher education. Educational Researcher, 31(5): 2834.

Bringle, R.G., Hatcher, J.A. (1996). Implementing Service-Learning in higher education. Journal of Higher Education. 67(2):221-239.

Cabanatan, Z. (1999). The role of the universities. Regional Meeting on the Role of Universities for Rural Development. 14-17 September 1998, Beijing.

Chauhan, N. B. (2012). Unit: iv rural development Head Department of Extension Education B.A.College of Agriculture, AAU, Anand.

Chambers, R. (1983). Rural Development. London: Longman.

Chatterton, P., Goddard, J. (2000). The Response of Higher Education Institutions to Regional Needs. European Journal of Education, 35 (4): $474-496$.

Council on Higher Education (CHE) (2004). Criteria for Programme Accreditation, Pretoria: Council on Higher Education

Darbi, W.P.K. (2012). Of Mission and Vision Statements and Their Potential Impact on Employee Behaviour and Attitudes: The Case of A Public But Profit-Oriented Tertiary Institution, International Journal of Business and Social Science, Ghana Institute of Management and Public Administration Business School, Accra, Ghana.

Furco, A. (2002). Is Service-Learning really better than community service? In A. Furco \& S. H. Billig (Eds.) Service-learning: The essence of pedagogy (p. 25). Greenwich, CT: Information Age Publishing.

Gustavo, A., Stamoulis, K. (2007). Rural Development and Poverty Reduction: Is Agriculture Still the Key? ESA Working Paper No. 0702 June 2007. www.fao.org/es/esa. Accessed 8 September 2013.

Gustavo, A., Lovendal, C., Nordanstad, M., Stamoulis, K. (2005). "Challenges in Addressing Hunger and Poverty in Bangladesh - The Case for a Twin-Track Approach," in Ministry of Food and Disaster Management and WFP, eds., Food Security in Bangladesh, Dhaka.

Hekkert, M., Suurs, R., Negro, S., Kuhlmann, S., Smits, R. (2007). Functions of innovation systems: A new approach for analysing technological change. Technological Forecasting \& Social Change , 413-432 .

Higher Education South Africa (HESA) (2012). Differentiation in Higher Education. http://www.hesa.org.za /sites/hesa.org.za/files/2012\%20HESA\%20Differentiation\%20Framework\%202012.pdf. Accessed 10 November 2013.

Isaacson, R., Sapertein, J. (2005). The Art \& strategy of service-learning presentation. Belmont, CA: Thomson Wadsworth.

Jacoby, B., Associates (2003). Building partnerships for service-learning San Francisco, CA: Jossey-Bass.

Johnston, B.F. (1970). Agriculture and Structural Transformations in Developing Countries: A Survey of the Research, Journal of Economic Literature, 8(2): 369-404.

Lele, U. (1975). The Design of Rural Development Lessons from Africa. Baltimore: Holt Rinbert.

Mabogunje, A.L. (1981). The Development Process: A spatial perspectives. Ibadan: Ibadan University Press.

Miller, B.A. (1995). The Role of Rural Schools in Community Development: Policy Issues and Implications. Journal of Research in Rural Education 11(3): 163-72.

Morphew CC, Hartly M 2006. Mission Statements: A Thematic Analysis of Rhetoric across Institutional type. Journal of Higher Education, 77 (3): 456 - 471

Mowery, D.C., Sampat, T. (2004). Universities in national innovation systems. In Fagerberg J, Mowery DC, Nelson RR (Eds) The Oxford Handbook of Innovation (p209 - 239). Oxford: Oxford University Press.

Opiyo-Newa, E. (2009). Assessing Higher Education: Relevance of Vision and Mission Statements: A Case Study of USIU, Journal of Language, Technology \& Entrepreneurship in Africa 1 (2): 112 - 119

Olayiwola, L. M., Adeleye, O.A. (2005). Rural development and agro-industrial promotion in Nigeria: concepts, strategies and challenges. Journal of Social Sciences, 11(1):57-61 
Özdem, G. (2011). An analysis of the mission and vision statements on the strategic plans of higher education institutions, Educational Sciences: Theory \& Practice 11(4): 1887-1894

Pearce, J., Pearson, M., Cameron, S. (2007). The Ivory Tower And Beyond: Bradford University At The Heart Of Its Communities: The Bradford University's Reap Approach To Measuring And Evaluating Community Engagement http://talloiresnetwork.tufts.edu/wpcontent/uploads/REAP_Report_Bradford_U.pdf. Accessed 10 October 2013

Policy Analysis and Advocacy Programme (2008) Reshaping Tertiary Agricultural Education In The ACP: 2015 And Beyond. Association for Strengthening Agricultural Research In Eastern And Central Africa (ASARECA) 11 (12): 1 - 8

Ramirez, A.S. (2010). The Role of Universities in Promoting Rural Innovation in Latin America. MSc Business Administration Thesis. Enschede: University of Twente

Raman, N. D. (1999). Regional Meeting on the Role of Universities for Rural Development 14-17 September 1998, Beijing

Rosenkranz, R.R. (2012). Service-learning in Higher Education Relevant to the Promotion of Physical Activity, Healthful Eating, and Prevention of Obesity. International Journal of Preventive Medicine. 3 (10): 672 - 681.

Singh, K. (1999). Rural development: principles, policies and management, Thousand Oaks, CA. Longman.

Subrahmanyam, C.V., Ravichandran, K. (2013). The role of universities in rural development. IQSR Journal of Business and Management 8 (5): 22-27.

Smith, C.T. (2005). Roles of mission statements in determining institutional scope, selecting performance criteria, and achieving successful learning outcomes, Minneapolis: Capella University

Swick, K. (2001). Service-learning in teacher education: Building learning communities. The Clearing House, 74(5): $261-264$.

The Presidency (2009). The Development Indicators 2009. www.thepresidency.gov.za/main.asp?include=learning /me/indicators/2009/index.html Accessed on 28 October 2009

Umbau, E. (2008). Agriculture and rural development. Rural development in the European Union-statistical and economic informationreport 2008. Accessed 21.12.2013. http://ec.europa.eu/agriculture.

UNESCO. (2006). Education for rural people in Africa. Report on seminar. Addis Abbab, September 2006. Accessed 21.12.2013. http://www.uneso.org.

World Bank (1975). Rural development: a policy paper. Washington D.C: World Bank. 